\title{
Intrauterine Device Insertion during Caesarean Section - A Boon for Rural Women.
}

\author{
Mishra Nidhi ${ }^{1}$, Dalal Neelesh ${ }^{2}$, Joshi Vrunda ${ }^{3}$ \\ ${ }^{123}$ Department of Obstetrics and Gynaecology, Bundelkhand Medical College, Sagar, India
}

\begin{abstract}
Objectives: To determine the safety of immediate post-placental intrauterine device insertion at the time of caesarean delivery. Method: This study was conducted in the Department of Obstetrics and Gynecology, Bundelkhand Medical College and associated Tili hospital, Sagar, from September 2010 to August 2011. Patients undergoing caesarean section for varied indications were counselled regarding intra-operative CuT380A insertion and those who agreed were allocated to the study group and the rest were allocated to the control group. The patients were observed during the post-operative period for complications associated with either caesarean section or intrauterine device insertion. Result: During the study period, 100 patients underwent CuT380A insertion immediately after removal of the placenta during caesarean delivery. There was no significant difference in the post-operative complication rates between both the groups. The rates for postoperative bleeding being 15\% in both the groups and that of post-operative infection being $5 \%$ and $7 \%$ in the study and control groups respectively.

Keywords: Complications, Intracaesarean, Intrauterine device insertion, Postplacental, Acceptance.
\end{abstract}

Accepted Date: 19 June 2013

\section{Introduction}

In referral centres such as ours, catering mostly to rural population where awareness and availability of contraceptive methods is less, when women undergo emergency caesarian section we are faced with a great dilemma ${ }^{1}$. If we counsel these women who come from far off villages at the time of discharge regarding contraception they are usually unable to come at six weeks because of either financial or social reasons. Hence they are subjected to the dangers of early pregnancy after caesarean section namely, septic abortion, obstructed labour, scar dehiscence, etc. which may endanger the life of these women.

Intrauterine contraceptive device is an age old method of contraception which has been studied at large $^{2}$ and postpartum intrauterine device insertion is also well known ${ }^{3,4}$. Hence, this method of contraception was studied in a new perspective to suit the need of these women. Intrauterine contraceptive device was inserted at the time of caesarean section after counselling ${ }^{5,6}$, when the patients and their relatives are most receptive to our advice and so, these patients were able to space their pregnancies without any added complications.

\section{Material And Method}

This was a study conducted from September 2010 to August 2011 in Tili Hospital, Sagar, M.P., a tertiary level care hospital (an associated hospital of Bundelkhand Medical college, Sagar). The objective was to determine the safety of immediate post-placental intrauterine device insertion at the time of caesarean delivery. The study was approved by the local institutional ethical committee.

Around 326 women underwent emergency caesarian section during the study period, out of which 126 women were excluded due to such factors like grand multipairty, impending rupture uterus, previous one or two caesarean sections, antepartum hemorrhage, etc. The remaining 200 women were counselled regarding intrauterine contraceptive devise insertion at the time of caesarean section and the 100 women who agreed for the procedure were allocated to the study group and the remaining 100 were allocated to the control group. Women in the study group underwent CuT $380 \mathrm{~A}$ insertion immediately after the removal of placenta during caesarean section.

Women in both the groups were followed up in the post-operative period and the number and frequency of complications was recorded and compared in both the groups. The data obtained in this study was tabulated and analysed using the Chi-square test and the $\mathrm{Z}$ test with $\mathrm{p}$ value of 0.05 taken as significant.

\section{Result}

Out of the 200 eligible women included for final analysis who underwent emergency caesarean sections, 100 women who agreed for intracaesarean intrauterine contraceptive device insertion after counselling 
Intrauterine device insertion during caesarean section - a boon for rural women.

were allocated to the study group and the remaining 100 were allocated to the control group. These women were observed during the post-operative period for the development of any complications.

The demographic characteristics for the women and indications for emergency caesarean sections were comparable for both the groups. The average age was 22.6 years in the study group and 24.2 years in the control group. $65 \%$ and $62 \%$ women were primigravida in the study group and control group respectively. The indication for caesarean section was cephalopelvic disproportion in 50\% of women in the study group and $61 \%$ of women in the control group.

The average duration of bleeding was 24.2 days in the study group and 21 days in the control group (table 2) (p 0.001). Only 15 women complained of severe bleeding in both the groups while rest of the women in both the groups experienced mild to moderate bleeding (table 2).Pain during the postoperative period was described as mild in $88 \%$ and $91 \%$ of women in the study and control group respectively (p 0.048) and as moderate in $12 \%$ and $9 \%$ of women in the study and control group respectively $(0.005)$. No woman in both the groups complained of severe pain (table 3 ).

There were three cases of postpartum endometritis in the study group and two cases in the control group. Abdominal wound infection occurred in one woman in the study group and five women in the control group, resulting in an overall infection rate of $4 \%$ in the study group and $7 \%$ in the control group (table 4) (p $0.005)$.

The intrauterine device was vaginally removed six hours postpartum in one intrauterine contraceptive device acceptor because of secondary postpartum haemorrhage.

\section{Tables}

Table - 1

Number of complications

\begin{tabular}{|llll|}
\hline Complications & Study group & Control group & P value \\
\hline Infection & 4 & 5 & 0.001 \\
Bleeding & 30 & 22 & 0.048 \\
Pain & 47 & 45 & 0.003 \\
Others & 0 & 0 & 0 \\
No complaints & 15 & 21 & 0.005 \\
\hline
\end{tabular}

Table - 2

Bleeding

\begin{tabular}{|c|c|c|c|c|}
\hline \multicolumn{2}{|l|}{ Bleeding } & Study group & $\begin{array}{l}\text { Control } \\
\text { group }\end{array}$ & $\mathrm{P}$ value \\
\hline \multirow{3}{*}{ Amount } & Mild & 30 & 38 & 0.003 \\
\hline & Moderate & 55 & 47 & 0.003 \\
\hline & Severe & 15 & 15 & 0.05 \\
\hline $\begin{array}{l}\text { Duration } \\
\text { days }\end{array}$ & & 24.2 & 21 & 0.001 \\
\hline
\end{tabular}

Table - 3

Pain during postpartum period

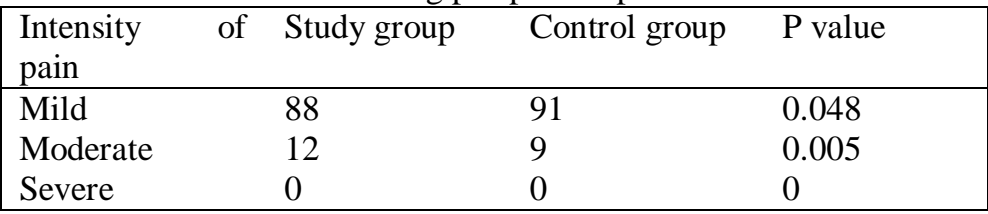

Table - 4

Type of infection

\begin{tabular}{|llll|}
\hline \multicolumn{1}{|c|}{ Type of infection } & $\begin{array}{l}\text { Study } \\
\text { group }\end{array}$ & $\begin{array}{l}\text { Control } \\
\text { group }\end{array}$ & P value \\
\hline $\begin{array}{l}\text { Postpartum endometritis } \\
\text { Abdominal wound } \\
\text { infection }\end{array}$ & 3 & 2 & 0.005 \\
\hline
\end{tabular}


Intrauterine device insertion during caesarean section - a boon for rural women.

\section{Conclusion}

We in Sagar cater to a rural population. The women in our villages are underprivileged and very much under social and financial pressure. Social issues prevent them from seeking early medical advice and help and hence, they are subjected to a lot of dangers of early pregnancy if they have to undergo emergency caesarean section. In this scenario, intrauterine contraceptive device insertion during caesarean section itself has proven to be a boon to these women.

In our study we found out that these women had minimal complications and the complications that did occur were the same as those associated with normal caesarean section without intrauterine device insertion. Thus from this study we have come to the conclusion that intraceasarean intrauterine device insertion can be a practical, safe, convenient and acceptable contraceptive method and with adequate selection of patients it can be a secure and helpful method for the fertility control for rural women with high risk of reproduction.

\section{Acknowledgement}

I am extremely grateful for the guidance and support provided by my seniors and colleagues, namely Dr Vrunda Joshi, Professor and head of the department, Dr Neelesh Dalal, Professor, Dr Shikha Pandey, Dr Jagriti Kiran Nagar, Dr Sheela Jain and all the OT staff.

\section{References}

[1]. Grimes DA, Lopez LM, Schulz KF, Van Vliet HA, Stanwood NL. Immediate postpartum insertion of intrauterine devices. Cochrane Database Syst Rev. 2010 May 12 ;( 5): CD003036. Review.

[2]. Xu JX, Connell C, Chi IC. Immediate postpartum intrauterine device insertion. AdvContracept. 1992 Dec;8(4):281-90. Review.

[3]. Penny G, Brechin S, deSouza A, et al. (2004) The copper contraception device as long-term contraception. J FamPlannReprod Health Care 30:29-41, quiz 42. Erratum in: J FamPlannReprod Health Care 2004;30:134.

[4]. Alvarez Pelayo J, BorbollaSala ME. IUD insertion during caesarean section and its most frequent complications. GinecolObstet Mex. 1994 Nov; 62:330-5. Spanish.

[5]. Levi E, Cantillo E, Ades V, Banks E, Murthy A. Immediate post placental Intrauterine device insertion at caesarean delivery: a prospective cohort study. Contraception 2012 Jan 20.

[6]. Kapp N, Curtis KM. Intrauterine device insertion during the postpartum period: a systematic review. Contraception. 2009 Oct, 80(4): 327-36.Epub 2009 Aug 29. 